\title{
HA ELMÚLT ÖTVENÖT ÉVES, MEGMONDJA AZ ÉLETKORÁT? AZ OSZKÁR SOFŐRÖK VISELKEDÉSÉNEK MODELLEZÉSE ${ }^{1}$
}

\author{
BERDE ÉVA, KUNCZ IZABELLA
}

\begin{abstract}
A platform gazdaságok egyik sajátossága, hogy az idősebb polgárok számára is munkavégzési lehetőséget biztosíthatnak. Olyanoknak is, akik önként vállalják ezt a módot, illetve olyanoknak, akik kiszorultak a munkaerőpiac egyéb szegmenseiből. Mindezt jól mutatja az Oszkár Telekocsi utastárs-közvetítő fejlődése, ahol a megalakulása óta nem csak a csatlakozott soförök száma növekedett többszörösére, de ezen belül az 55 évesek és idősebbek aránya is emelkedett. Az Oszkár, mint a legtöbb platform, lehetőséget ad arra, hogy a szolgáltatást kínálók jelezzék életkorukat, sokan azonban ezt nem teszik meg. Tanulmányunkban egy bayesi játékelméleti modellel bizonyítjuk, hogy az idősebbek részére valóban egyensúlyi megoldást jelenthet, ha nem mindig jelzik korukat. Ugyanezt az eredményt adja két részletben végzett rövid online felmérésünk is.
\end{abstract}

JEL kód: C72, J00, L19

Kulcsszavak: Platform gazdaság, idősebb sofőrök, on-line felmérés, játékelméleti modell

\section{Bevezetés}

A várható élettartam emelkedése, és ezzel együtt az egészségben eltölthető évek számának növekedése lehetővé teszi, hogy a munkaerő-piacon töltött idő is meghosszabbodjon. Az európai jóléti államok többségében azonban egészen az 1980as évek közepéig még viszonylag alacsony korhatár mellett élvezhette az idősebb korosztály a nyugdíjba vonulás kényelmét, és az ehhez kapcsolódó relatív anyagi jólétet. Általánosan elfogadott nézet volt, hogy az idősebb korosztály „kötelessége", hogy kivonuljon a munkapiacról, átadva helyét a fiatalabb generációnak. Szélsőséges példaként hozható fel a jelenségre az Ilmakunnas és Maliranta (2007) által bemutatott úgynevezett „Walmart-hatás”, miszerint a vállalati vezetés már a középkorú alkalmazottakat is igyekezett hatékonyabb, fiatalabb munkaerővel helyettesíteni.

\footnotetext{
${ }^{1}$ Jelen publikáció/kutatás az Európai Unió, Magyarország és az Európai Szociális Alap társfinanszírozása által biztosított forrásból az EFOP-3.6.2-16-2017-00017 azonosítójú „Fenntartható, intelligens és befogadó regionális és városi modellek" címü projekt keretében jött létre.
} 
A lakosság öregedésével párhuzamosan az 1980-as évek végétől kezdődően a legtöbb európai országban elindult a nyugdíjkorhatár emelése, és a kormányzatok igyekeztek népszerüsíteni az idősebb korúak munkájának hasznosságát. A PwC (2018) az ún. „Aranykor Index²” segítségével úgy becsülte, hogy 2016-ban a Gazdasági Együttmüködési és Fejlesztési Szervezet (Organization for Economic Co-operation and Development, OECD) országainak GDP értéke hosszú távon összesen 3,5 billió dollárral lenne magasabb, ha az 55-64 éves korosztály foglalkoztatási rátája elérné az Új-Zélandon megfigyelt 78\%-os értéket ${ }^{3}$. A kormányzat szándékát azonban nemcsak az idősebb generáció személyes motivációjának hiánya akadályozza, hanem a társadalomban rögzült elképzelések és a vállalati szintü stratégiák is.

Cikkünkben a társadalmi meggyőződés egy sajátos megnyilvánulásával foglalkozunk. Hipotézisünk szerint az idősebb polgárokat negatív megkülönböztetés éri - vagy legalábbis ők úgy érzik, hogy megkülönböztetéssel szembesülnek - a munkakeresés során, de nemcsak a hagyományos foglalkoztatási formák, hanem az online platformokon keresztül elérhető munkalehetőségek esetében is. Azt állítjuk, hogy az idősebb korosztály próbál alkalmazkodni a jelenlegi körülményekhez, és emiatt vagy szándékosan tévesen, vagy egyáltalán nem adják meg életkorukat. Ezzel szemben a fiatalabb, 30-55 éves korosztálynak megéri bevallani a valós korát.

Az idősebbek foglalkoztatottsága Magyarországon a 2000-es évektől kezdve rohamosan növekedett. A KSH adatai szerint 2002 és 2018 közt az 55-59 évesek foglalkoztatottsága több mint 30\%ponttal emelkedett, a 60-64 éveseké pedig majdnem 30\%ponttal. Az 55-59 évesek által elért szint, a 74\% meghaladta az EU megfelelő átlagát, a 60-64 évesek 38,2\%-a azonban még mindig több mint 6\%ponttal maradt el korosztályuk EU átlagától. Mint ahogy azonban Button (2019) is írta, a szeniorok hagyományos, sztenderd munkavégzése sokkal kisebb arányú, mint a fiatalabbaké. Amikor ők jelentkeznek egy állásinterjúra, akkor nekik sokkal kisebb az esélyük arra, hogy visszahívást kapjanak. Sokan válnak közülük önfoglalkoztatóvá, illetve jó lehetőséget jelent számukra az olyan típusú platformokon keresztül végzett munka, melyről jelen cikkünk szól.

A fentieket alátámasztva Berde és Tókés (2020) a magyar Oszkár ${ }^{4}$ útitárskereső platform adatainak elemzésekor úgy találták, hogy átlagosan az alkalmazást használó soförök 30-40\%-a nem adja meg életkorát az adatlapján. Természetesen ez nem jelenti azt, hogy csak az idősebb felhasználók hagyják üresen ezt az információt, valószínüleg mások is így tesznek, fóként a nagyon fiatalok.

\footnotetext{
${ }^{2} \mathrm{Az}$ „Aranykor Index (angolul Golden Age Index) egy olyan kompozit index, mely hét mutató súlyozott átlagaként az 55 évesek és idősebbek munkaerö-piaci hatását méri. Legnagyobb súlya az indexben az 55-64 évesek foglalkoztatási rátájának van.

${ }^{3}$ Új-Zélandon, Izlandon, és Svédországban a legmagasabb a vizsgált korosztály foglalkoztatottsága PwC (2018) szerint.

${ }^{4}$ A 2007-es alapításakor az Oszkár alapvetően egy telekocsi szolgáltatás volt, azonban Berde és Tőkés (2020) az Oszkár adatok alapján megállapította, hogy napjainkban egyre inkább a kereskedelmi céllal meghirdetett utak kerülnek túlsúlyba.
} 
A 30-55 év közti korosztály azonban véleményünk szerint inkább figyelmetlenségből, és nem tudatosan tartja titokban életkorát. Berde és Tőkés (2020) arra is felhívják a figyelmet, hogy Huws et al. (2017) állításával ellentétben, az idősebbek is szívesen használnak online platformokat munkavégzési céllal. Legalábbis az Oszkár esetében az 55 éves vagy idősebb soförök aránya emelkedett, miközben a platform jármüvezetőinek teljes létszáma is nőtt. Emiatt különösen fontos kérdés, hogy hogyan viselkednek az idősebb munkavállalók a hasonló jellegü online platformokon. Elemzésünk során így eltekintünk a fiatalabb korosztálytól, és modellünkben csak az idősebb soföröket szerepeltetjük.

Hipotézisünket, miszerint az idősebb korosztály inkább eltitkolja életkorát, egy online kérdőíves felmérés segítségével bizonyítjuk. A kérdőív eredményeit a cikk második részében mutatjuk be. A harmadik részben egy jól ismert játékelméleti modell segítségével támasztjuk alá állításunkat az idősebb korcsoportok stratégiáját illetöen. Végül összefoglaljuk következtetéseinket.

\section{Az online kérdőív}

Az online felmérésünkben összesen öt kérdést tettünk fel, melyek a kérdőív teljes szövegével együtt az A. Függelékben olvashatók. A kitöltőknek elsőként a nemüket és a születési évüket kellett megadni. Majd arról érdeklődtünk, hogy véleményük szerint az internetes platformokon kínált szolgáltatások esetén - például sofőrködés, takarítás, korrepetálás - figyelembe veszik-e az ügyfelek a hirdető életkorát. A következő kérdésünk arra irányult, hogy amennyiben lehetséges az életkoruk megadása, de nem kötelező (és annak valósságát sem ellenőrzik), kitöltenék-e az erre vonatkozó részt az internetes felületeken. Végül abban az esetben, ha az előző kérdésnél úgy döntöttek, hogy beírnának egy életkort, azt kellett megválaszolniuk, hogy hány évesként tüntetnék fel magukat.

Az online kérdőívet olyan levelezési listákon és Facebook csoportokban terjesztettük, ahol a legtöbb résztvevő 55 éven felüli. Első körben 2018 júniusától 2018 augusztusáig gyüjtöttük a válaszokat ${ }^{5}$ elsősorban bizonyos levelező listákon keresztül, majd 2019 áprilisában és májusában Facebook csoportokat céloztunk meg. Ekkor is olyan csoportokat választottunk, ahol alapvetően az idősebb korosztály alkotta a tagságot. Összesen 241 ember töltötte ki a kérdőívünket, akik közül a legfiatalabb 20 éves, a legidősebb pedig 78 éves volt. Miután a mintából kivettük az 55 év alattiakat, 147 kitöltőnk maradt. A kapott válaszok megoszlását és a válaszolók nem szerinti megoszlását az 1. táblázatban foglaljuk össze.

\footnotetext{
${ }^{5} \mathrm{Az}$ első szakaszban végzett felmérés eredményeiről Berde (2019) számol be.
} 
1. táblázat. A kapott válaszok megoszlása az 55 évesek és idősebbek korcsoportjában.

\begin{tabular}{|l|c|c|}
\hline Nem & Férfi & Nő \\
& $37,4 \%$ & $62,6 \%$ \\
\hline Véleménye szerint életkorának van jelentösége & Igen & $\mathrm{Nem}$ \\
abban, hogy mennyi ügyfele lesz? & $82,3 \%$ & $17,7 \%$ \\
\hline Ön megadna & Igen & $\mathrm{Nem}$ \\
valamilyen életkort? & $55,8 \%$ & $44,2 \%$ \\
\hline Azok, akik szerint & $\mathrm{Igen}$ & $\mathrm{Nem}$ \\
számít az életkor, megadnák az életkorukat? & $46,3 \%^{6}$ & $53,7 \%$ \\
\hline Azok, akik szerint & $\mathrm{Igen}$ & $\mathrm{Nem}$ \\
nem számít az életkor, megadnák az életkorukat? & $100 \%^{7}$ & $0 \%$ \\
\hline
\end{tabular}

Az online felmérésünk nem tekinthető reprezentatívnak, mert sajátos módon terjesztettük. Egy bizonyos Facebook csoporthoz, vagy levelező listához való tartozás eleve egyfajta önszelekción alapul. Ennek ellenére kérdőívünkből úgy tünik, hogy a megkérdezettek többsége szerint az életkor szignifikáns tényező a tekintetben, hogy igénybe veszik-e az általuk kínált szolgáltatást, vagy sem. Tanulmányunk következő részében megmutatjuk, hogy egy Cho és Kreps (1987) és Kreps (1990) által alkalmazott bayesi játék modellje is a hipotézisünknek megfelelő következtetésre vezet.

\section{A modell}

\subsection{A modell elméleti háttere}

Modellünk két ismert játékelméleti fogalmat használ, a munkapiaci jelzést és a Harsányi-féle transzformációt, mely a nem-teljes információjú játékokat nemtökéletes információjú játékokká alakítja át, azaz áttranszformálja azt a helyeztet, amikor az egyik játékos valamit nem tud a másik játékosról, egy olyan helyzetté, amikor az egyik játékos azt nem tudja, hogy a másik játékos mit lépett a játék megelőző fázisában. A munkapiaci jelzés elméletét elsőként Spence (1973) vezette be. Ennek lényege, hogy a munkaadó olyan szerződést ajánl, melyben a kifizetett bér a munkavállaló végbizonyítvánnyal vagy diplomával igazolt iskolázottsági szintjének függvénye. A valódi kompetenciaszintjét azonban csak saját maga, a munkavállaló ismeri, és azt nem feltétlenül tükrözi a végzettsége. Egy egyetemi diplomával rendelkező, de kevésbé alkalmas személy így magasabb bérhez juthat hozzá, mint

\footnotetext{
${ }^{6}$ Azok százalékában, akik szerint számít az életkor.

${ }^{7}$ Azok százalékában, akik szerint nem számít az életkor.
} 
egy hasonló képességű nem diplomás egyén. Bár a jelzés bevezetése a munkapiacon Spence (1973) érdeme, hasonló gondolatok megjelentek Arrow (1973), Mincer (1974) és Stiglitz (1975) tanulmányaiban is. A munkavállalói szerződések vizsgálatának leggyakoribb eszközét, a Spence-féle jelzést alkalmazza többek között Lazear és Rosen (1981), Hanushek (1986), Heckman et al. (2006) és Slee (2017), melyek közül ez utóbbi tanulmányunk szempontjából a leginkább releváns. Slee (2017) rávilágít arra, hogy az úgynevezett hakni gazdaságban ${ }^{8}$ (angolul gig economy) online felületen keresztül végzett munka minősítési rendszere alapján úgy tünhet, hogy az emberek teljesítményének értékelése objektív módon történik, vagyis az értékelés a munkájuk minőségét tükrözi. Slee azonban bebizonyítja, hogy a valóságban ezek az értékelések sokkal inkább előítéleteken alapulnak, mint a felettesek által adott hagyományos minősítések. A hakni gazdaságban dolgozók emiatt arra kényszerülnek, hogy olyan jelzéseket küldjenek, melyekkel ellensúlyozhatják az előítéleteket és jobb értékelést kaphatnak (például megpróbálhatják elrejteni a helyi etnikai kisebbséghez való tartozásukat).

Az olyan szituációkat, amikor egyes játékosok birtokában vannak bizonyos ismeretnek, míg másokénak nem, hiányos vagy nem-teljes információjú játékoknak nevezzük. Ilyen típusú ismeret lehet például az életkor, az alkalmasság, stb. Harsányi (1967, 1968a, 1968b) megmutatta, hogyan lehet a nem-teljes információs játékokat nem-tökéletes információssá alakítani a „Véletlen”, mint elsőként lépő játékos bevezetésével. A Véletlennek nincsenek kifizetései, de meghatározza a játékosok típusát. A játékosok ezután cselekedeteikkel jelezhetik típusukat, így például Spence (1973) modelljében a tehetségesebb egyének kisebb erőfeszítéssel képesek elvégezni az egyetemet, így nagyobb valószínüséggel szereznek diplomát. A játékosok viszont megpróbálhatnak a típusuktól eltérő jelzést küldeni, hogy magasabb kifizetéshez jussanak, mint az előző példában megjelenített rosszabb képességü, de diplomás munkavállaló. Mivel a másik játékos csak a megfigyelt jelzés alapján feltételezheti az előbbiek típusát, így az azonos jelzést küldő egyének ugyanabba az információs halmazba kerülnek. Roth és Sotomayor (1992) ezzel a megközelítési móddal modellezte a munkapiacot. Osborne és Rubinstein (1994) szintén tartalmazza a Harsányi-transzformációt, ahol emellett hangsúlyozzák a külső körülmények szerepét is. Azt állítják, hogy a körülmények függenek a játékosok viselkedésétől, és ez fordítva is igaz, a játékosok viselkedésére befolyással vannak a külső körülmények. Az alábbiakban bemutatott modellünk a fentiekben kifejtett alapelvekre épül ${ }^{9}$.

\footnotetext{
${ }^{8}$ A foglalkoztatás atipikus formája, melybe az informális munkavállalás azon formái tartoznak, ahol online platformon keresztül vállalnak alkalmi jellegü munkát.

${ }^{9} \mathrm{Az}$ extenzív forma leírásakor és az ott alkalmazott akciók jelölésekor, illetve mindezek játékelméleti hátterének bemutatásakor részben támaszkodtunk Berde (2019)-re.
} 


\subsection{A modell felépítése és eredményei}

Modellünkben két típusú soför található ${ }^{10}$. Az egyik típus úgy véli, hogy az életkor nem számít, attól függetlenül választják őt a fogyasztók. Jelöljük ezt a típust R-rel („,regardless”)! A másik típus vele szemben azt gondolja, hogy igenis számít az életkor, így például az időseb sofőrök kevesebb megbízást kapnak. Ez utóbbi típust M-mel jelöljük („matters”). Szolgáltatásuk meghirdetéséhez mindannyian regisztrálnak egy online platformon az adatlap kitöltésével, melyben nem kötelező minden kérdést megválaszolni, így például nem feltétlenül szükséges megadni életkorukat. Mivel a valóságban nem ellenőrzik az adatok helyességét, előfordulhat, hogy hamis információt jelenítenek meg. Modellünkben azonban eltekintünk a hazugság lehetőségétől ${ }^{11}$, így az alábbiakban csak az életkor eltitkolása, vagy a valós életkor bevallása a szereplők két opciója.

Az utasok látják az adatlapon a soför feltüntetett életkorát. Természetesen gyakrabban találkoznak fiatalabb soförrel, mint időssel, modellünkben azonban az idősebb soförökre koncentrálunk. Az idősebb soföröket vizsgálva azt elemezzük, hogy mennyire érdemes a soförnek közölnie tényleges életkorát. Amikor a soför meghirdet egy utat, a potenciális utas vagy elfogadja az utazás lehetőségét és jelentkezik, vagy nem. A döntés során mérlegelt egyik információ a sofőr életkora, ami előfordulhat, hogy nincs megadva. Ebben az esetben az utas nem tudja, hogy miért hiányzik ez az információ (azért, mert a soför túl idős, vagy azért, mert egyszerűen átsiklott felette az adatlap kitöltésekor). Mi a modellünkben eltekintettünk azoktól az esetektől, amikor valaki figyelmetlenségből nem írta be az életkort. Kérdőíves felmérésünk azt mutatta, hogy az 55 éven felüliek döntő része úgy gondolja, hogy az életkor releváns tényező akkor, amikor egy alkalmi munka végzésekor a „megrendelő” kiválasztja őket. A megkérdezettek mindössze 17,7 százaléka válaszolt kérdésünkre úgy, hogy nem számít az életkor, azaz modellbeli kategorizálásunk szerint csak ennyien voltak R típusúak.

A kifizetéseket Cho és Kreps (1987) játékához hasonlóan adtuk meg. Akárcsak Cho és Kreps, mi is csak a kifizetések egymáshoz képest vett értékének tulajdonítottunk jelentőséget: a sofőr akkor jár jobban, ha típusának megfelelően viselkedik, az utasnak pedig azt a sofört érdemes inkább elfogadnia, aki szerint nem számít az életkor. Ezt számszerüsítve: az utas kifizetése 1, ha a sofőrrel típusának meg-

\footnotetext{
${ }^{10}$ Ahogy azt már korábban a bevezetésben jeleztük, modellünk csak az idősebb sofőrökre vonatkozik. Feltesszük, hogy az utas egyrészt egyéb információkból - pl. a fényképből, vagy a fénykép helyére feltöltött más képből, illetve a soför vezetési történetéből - akkor is következtetni tud arra, hogy fiatalabb vagy idősebb soförrel áll szemben, ha a soför adatlapján nincs ott az életkor. Továbbá feltesszük, hogy az utas bizonyos esetekben az idősebb sofört is elfogadja. Hogy milyen esetekben fogadja el, ezt vizsgáljuk a modellben.

${ }^{11}$ A mintánkban azok szerint is, akik úgy vélték, számít az életkor, eleve csak $5 \%$ nyilatkozott úgy, hogy más életkort ír be, mint a tényleges életkora. Válaszukban minden bizonnyal szerepet játszott az is, hogy ha valaki hazudik, akkor nem szívesen árulja el, hogy hazudik. Ezzel együtt a más életkort bevallók számát nem tekintettük szignifikánsnak, és csak arra figyeltünk, hogy valaki bevallja-e az életkorát, vagy sem.
} 
felelően viselkedik, vagyis elfogadja annak a szolgáltatását, aki szerint az életkor nem számít, és elutasítja azét, aki szerint számít. Ellenkező esetben az utasok kifizetése 0. A 2. táblázatban összefoglaljuk az utas kifizetését.

2. táblázat. Az utas kifizetései a soför elfogadása, illetve elutasítása esetén.

\begin{tabular}{|c|c|c|}
\hline & R típusú & M típusú \\
\hline Elfogadja & 1 & 0 \\
\hline Nem fogadja el & 0 & 1 \\
\hline
\end{tabular}

Mivel az utas nem tudja közvetlenül megfigyelni a sofőr típusát, csak azt, hogy megadta-e életkorát vagy sem, a sofőr számára az életkor megadása egy jelzés, amely saját típusától függően különböző kifizetést biztosít számára, miközben befolyásolja az utas döntését. A soför jelzések által megszerzett kifizetéseit a 3. táblázatban foglaljuk össze.

3. táblázat. A sofőr kifizetései az életkor megadása és elrejtése esetén.

\begin{tabular}{|c|c|c|}
\hline & R típusú & M típusú \\
\hline Megadja életkorát & 1 & 0 \\
\hline Nem adja meg életkorát & 0 & 1 \\
\hline
\end{tabular}

A soför kifizetése azonban nagyobb mértékben függ attól, hogy az utas elfogadja-e őt, vagy sem. Ezeket a kifizetéseket a 4. táblázat tartalmazza.

4. táblázat. A soför kifizetései ajánlatának elfogadása és elutasítása esetén.

\begin{tabular}{|c|c|c|}
\hline & R típusú & M típusú \\
\hline Elfogadja az utas & 2 & 2 \\
\hline Nem fogadja el az utas & 0 & 0 \\
\hline
\end{tabular}

A különböző kifizetéseik összeadódnak, így a 3. és a 4. táblázat alapján az R típusú sofőr kifizetése, ha megadja életkorát, és az utas elfogadja a szolgáltatását, összesen 3. Ha megadja életkorát, de nem fogadja el az utas, akkor a kifizetése 1. Amennyiben nem jeleníti meg korát, de szolgáltatását elfogadja az utas, akkor 2, ha pedig nem fogadja el, akkor 0. Az M típusú sofór kifizetéseit is hasonlóképpen, additív módon adhatjuk meg. Amennyiben M típusával ellentétesen bevallja az életkorát, és elfogadja őt az utas, akkor 2 a kifizetése, viszont, ha nem vallja be az életkorát, és nem fogadja el őt az utas, akkor csak 1 kifizetéshez jut. Ezért, ha az 
életkor megadásával rá tudja venni az utast, hogy fogadja őt el, akkor érdemes feladnia a jellemének megfelelő viselkedésformát, hisz ezzel növeli a jóléti helyzetét. A játék normál formáját az 1. ábra tartalmazza. A kifizetések (hasonló számításokat tartalmaz Binmore (1992) 464. oldalának 10.11 ábrája) az 5. táblázatban láthatók. Az 5. táblázat kifizetéseinek kiszámításakor figyelembe vettük, hogy egy idősebb sofôr a kérdőíves felmérésünk alapján 0,177 valószínüséggel $\mathrm{R}$ típusú, és így értelemszerüen 0,823 valószínüséggel $\mathrm{M}$ típusú.

5. táblázat. Az utas-sofór interakciójának kifizetési mátrixa.

Utas

\begin{tabular}{|c|c|c|c|c|c|}
\hline \multirow{5}{*}{ Soför } & \multirow[b]{2}{*}{$\mathrm{mm}$} & $e e$ & en & $n e$ & $n n$ \\
\hline & & $(2,18 ; 0,18)$ & $(2,18 ; 0,18)$ & $(0,18 ; 0,82)$ & $(0,18 ; 0,82)$ \\
\hline & \multirow{2}{*}{$\begin{array}{l}m n \\
n m\end{array}$} & $(3,00 ; 0,18)$ & $(1,35 ; 1,00)$ & $(2,65 ; 0,00)$ & $(1,00 ; 0,82)$ \\
\hline & & $(2,00 ; 0,18)$ & $(1,65 ; 0,00)$ & $(0,35 ; 1,00)$ & $(0,00 ; 0,82)$ \\
\hline & $n n$ & $(2,82 ; 0,18)$ & $(0,82 ; 0,82)$ & $(2,82 ; 0,18)$ & $(0,82 ; 0,82)$ \\
\hline
\end{tabular}

- $m$ : megadja az életkorát, $n$ : nem adja meg

- $e$ : elfogadja az ajánlatot, $n$ : nem fogadja el.

Az 5. táblázatban a zárójelben lévő első érték a soför, a második pedig az utas várható kifizetése. A soför soraiban a betüpárok első tagja minden esetben az $\mathrm{R}$ típusú, a második pedig az M típusú sofőrre vonatkozik, illetve az utas oszlopaiban az első betü a válasz a soför $m$ stratégiájára, a második pedig az $n$-re.

Az 5. táblázat által bemutatott kifizetési mátrixnak nincsen tiszta stratégiai Nash-egyensúlya, ezért a kevert stratégiai egyensúlyt lehet csak meghatározni. Ez a négyszer négyes mátrix esetében ugyan hagyományos úton is kiszámítható, de tanulságosabb inkább a Cho és Kreps (1987) modelljén alapuló és Binmore (1992)-ben is leírt érvelést alkalmazunk. Azaz Harsányi-transzformáció segítségével alakítjuk át a nem-teljes információjú játékot nem-tökéletes információjú játékká. Vagyis egy olyan szituációt, amikor az utas nevü játékos nem ismeri a sofőr nevü játékos típusát, átalakítunk egy másik szituációvá. Ezek szerint az utas nevü játékos csak azt tudja, hogy a sofőr nevü játékos megadja-e az életkorát vagy sem, és ebből következtet a sofőr nevü játékos típusára.

Bevezetünk a játékba egy új szereplöt, nevezzük ôt Véletlennek, akinek nincs kifizetése, és a szerepe annyi, hogy ő határozza meg, hogy az idősebb sofőr R vagy M típusú lesz-e. A játék fáját az 1. ábra tartalmazza.

A Harsányi-transzformációval nem-tökéletes információjúvá alakított játékban két információs halmaz szerepel. Az egyik információs halmazba azok a soförök tartoznak, akik megadják életkorukat, ezt nevezzük „Declare” (Bejelent) információs halmaznak. Az R típusú soför $\mathrm{D}$ valószínüséggel, az M típusú sofór d valószínü- 
1. ábra. Az idősebb sofór és az utas interakciójának extenzív formája

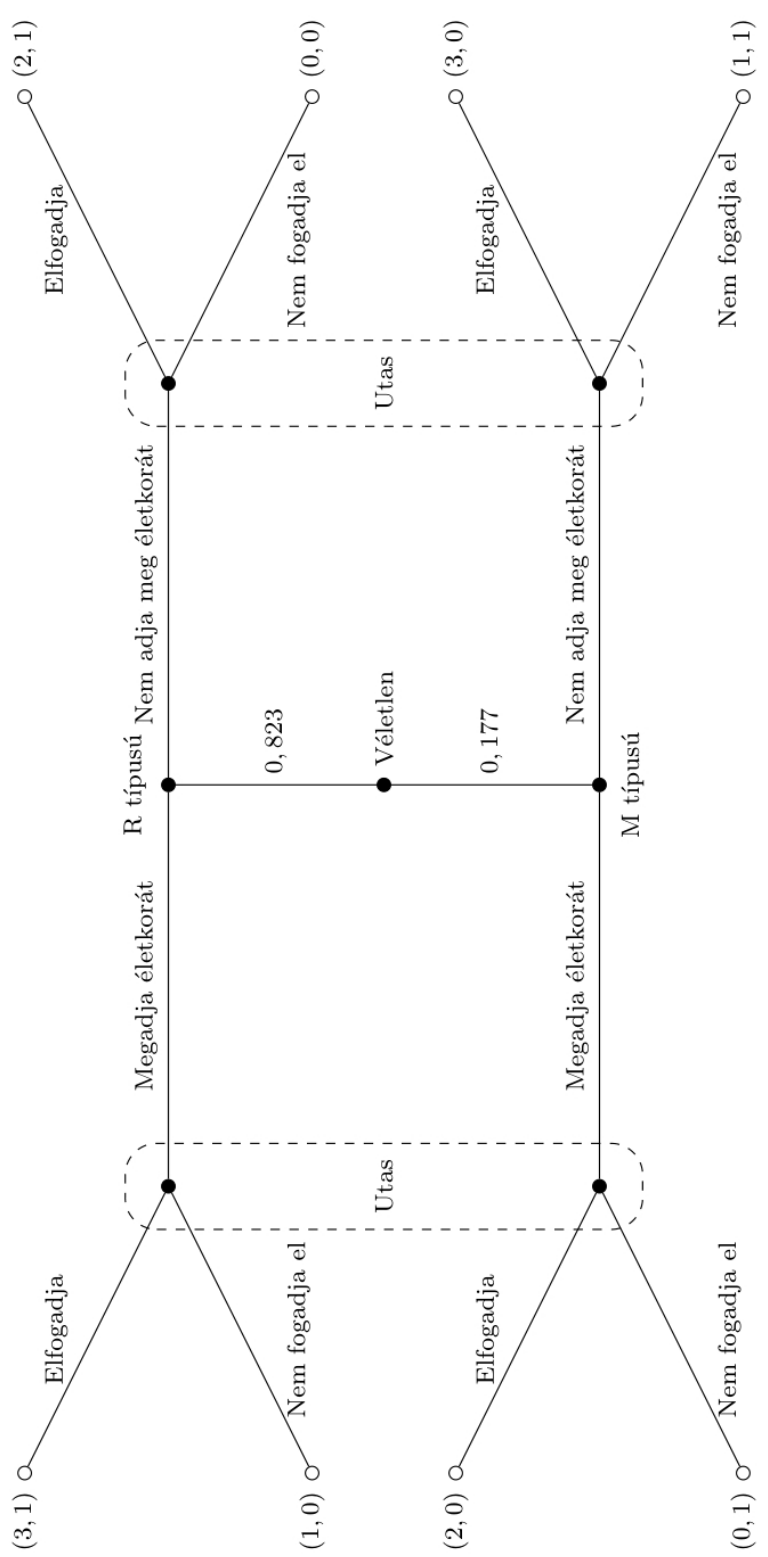


séggel adja meg az életkorát. A „None given” (Nem ad meg) információs halmazba az R típusú soför $N G$, az M típusú pedig $n g$ valószínüséggel kerül. Értelemszerüen $N G+D=1$, és $n g+d=1$.

Az utas, ahogy azt már korábban említettük, a sofór által küldött jelzést tudja csak megfigyelni, ami az életkor megadása vagy elrejtése. Mind a megadott, mind az elrejtett életkor esetén akkor fogadja el a sofórt, ha úgy véli, hogy a soför nagyobb valószínüséggel $\mathrm{R}$, mint $\mathrm{M}$ típusú.

A Bayes-tétel segítségével felírva a „None Given” információs halmazban az utas akkor fogadja el a sofört, ha

$$
P(\text { R típusú } \mid \text { Nem ad meg })>P(\text { M típusú } \mid \text { Nem ad meg }),
$$

vagyis esetünkben ha

$$
\frac{0,177 N G}{0,177 N G+0,823 n g}>\frac{0,823 n g}{0,177 N G+0,823 n g},
$$

amiből

$$
N G>4,6497 n g,
$$

és nem fogadja el a sofort, ha

$$
N G<4,6497 n g .
$$

Az utasnak randomizálnia kell az egyensúlyi helyzetben (különben lenne tiszta stratégiai Nash-egyensúly). Ha a „None Given” halmazban randomizál, akkor

$$
N G=4,6497 n g .
$$

Emiatt

$$
1-D=4,6497-4,6497 d,
$$

és így

$$
4,6497 d=3,6497+D .
$$

Hasonlóképpen az utas a „Declare” információs halmazban akkor fogadja el a sofört, ha

$$
\frac{0,177 D}{0,177 D+0,823 d}>\frac{0,823 d}{0,177 D+0,823 d},
$$

vagyis ha

$$
D>4,6497 d
$$

és nem fogadja el a sofort, ha

$$
D<4,6497 d \text {. }
$$

A (7) és (10) alapján ha az utas randomizál a „None Given” információs halmazban, akkor nem fogadja el a sofört a „Declare” információs halmazban. Ezért semmi 
értelme, hogy az M típus bevallja életkorát, azaz $n g=1$, és így (5) alapján $N G=$ 4,6497, ami lehetetlen.

Mindezek következtében az idősebb sofőr és az utas találkozásának csak olyan kevert stratégiai egyensúlya van, ahol csak a „Declare” információs halmazban randomizál az utas, tehát

$$
D=4,6497 d
$$

ami azt jelenti, hogy

$$
1-N G=4,6497-4,6497 n g,
$$

vagyis

$$
N G=4,6497 n g-3,6497 \text {. }
$$

Mivel ekkor

$$
N G<4,6497 n g,
$$

a „None Given” információs halmazban nem fogadja el az utas a sofort. Így az $\mathrm{R}$ típusnak érdemes mindig bevallania az életkorát, $D=1$ és (11) alapján $d=$ 0,2151. Ami azt mutatja, hogy az M típusú sofor randomizál a „None given” és a „Declare” akció közt. A „None Given” akció mellett a kifizetése 1, ezért a „Declare” információs halmazban is 1 kell, hogy legyen a kifizetése. Ezt akkor éri el, ha $\theta$-val jelölve annak valószínüségét, hogy az utas elfogadja öt,

$$
1=0+2 \theta
$$

vagyis

$$
\theta=\frac{1}{2}
$$

Végeredményben az $\mathrm{R}$ típusú sofőr mindig bevallja életkorát, az $\mathrm{M}$ típusú pedig 0,2151 valószínüséggel vallja azt be. A „None Given” információs halmazban az utas sose fogadja el a sofört, és a „Declare” információs halmazban 1/2 valószínüséggel fogadja őt el.

Kérdőíves felmérésünk szerint is az M típusú idősebb soförök felénél kevesebb adná meg életkorát. A Cho and Kreps (1987) modell gondolatait alkalmazva még ennél is alacsonyabb értéket kapunk, ami azonban egyértelmüen függ attól, hogy az egyes viselkedésmódok milyen számszerü kifizetést eredményeznek. A modell kifizetése esetén elvi jelentése a kifizetések egymáshoz való viszonyának van: ha valaki a típusának megfelelő viselkedést tanúsít, akkor azzal kisebb előnyhöz jut, mint azzal, ha elfogadtatja magát. Ezek a következtetések teljesen megfelelnek a kérdőíves felmérésünk eredményeinek is. Bár a válaszolók közül körülbelül 82,3\%-a gondolta azt, hogy számít a kor, de még közülük is körülbelül 46\%-uk beírná a korát az adatlapra, vagyis rossz érzése ellenére nyilatkozna születési dátumáról.

Véleményünk szerint az M típusúak nagy aránya elsősorban a társadalmi értékítélet következménye, mely szerint az idősebbek nem alkalmasak hatékony munkavégzésre. Az utasszállításra vállalkozó idősebb polgárok valószínüleg ezért nem 
írják le szívesen az életkorukat. Kérdés azonban, hogy mennyire kellene megnövekednie az $\mathrm{R}$ típusúak arányának ahhoz, hogy mind az $\mathrm{R}$ mind az $\mathrm{M}$ típusú sofórnek megérje bevallania életkorát. Belátható, hogy $x$-szel jelölve az $\mathrm{R}$ típusúak részarányát, mindaddig, amíg $x<1 / 2$, az utasnak nem érdemes elfogadnia a sofórt a „Non given” információs halmazban, a „Declare” információs halmazban pedig érdemes randomizálnia. Ennek hatására az R típusú sofőr mindig bevallja életkorát, az $\mathrm{M}$ típusú pedig $x /(1-x)$ valószínüséggel vallja azt be. Amennyiben az $\mathrm{R}$ típusú valószínüsége 1/2-nél nagyobb lesz, akkor a játéknak létezik tiszta stratégiai egyensúlya, mint ahogy a 6. táblázat alapján látható. Az egyensúlyt (feltéve, hogy $x$ mindig valamivel 1 alatt marad) az $(m m ; e n)$ illetve az $(n n ; n e)$ stratégiapárosok alkotják.

6. táblázat. Kifizetési mátrix

Utas

\begin{tabular}{|c|c|c|c|c|c|}
\hline \multirow{5}{*}{ Soför } & \multirow[b]{2}{*}{$m m$} & $e e$ & en & $n e$ & $n n$ \\
\hline & & $3 x+2(1-x) ; x$ & $3 x+2(1-x) ; x$ & $x ; 1-x$ & $x ; 1-x$ \\
\hline & $m n$ & $3 x+3(1-x) ; x$ & $3 x+(1-x) ; 1$ & $x+3(1-x) ; 0$ & $x+(1-x) ; 1-x$ \\
\hline & $n m$ & $2 x+2(1-x) ; x$ & $2(1-x) ; 0$ & $2 x ; 1$ & $0 ; 1-x$ \\
\hline & $n n$ & $2 x+3(1-x) ; x$ & $1-x ; 1-x$ & $2 x+3(1-x) ; x$ & $1-x ; 1-x$ \\
\hline
\end{tabular}

A 6. táblázat celláiban lévő első értékek a sofőr, a második pedig az utas várható kifizetései. A sofőr soraiban a stratégiát jelző betűpárosok első tagja minden esetben az $\mathrm{R}$ típusú, a második pedig az $\mathrm{M}$ típusú sofórre vonatkozik, illetve az utas oszlopaiban az első betü válasz a sofór $m$ akciójára, a második pedig az $n$-re. További jelölés: $x$ az R típusú, $(1-x)$ az M típusú soförök aránya a populációban.

Abban az esetben, ha $1-x>x$, nincs egyensúly a tiszta stratégiák halmazán. Ha $x>1-x($ azaz $x<1 / 2)$, akkor viszont van: $(m m ; e n)$ és $(n n ; n e)$. Vagyis vagy mindkét típus megadja az életkorát, és az utas megadott életkor esetén elfogadja az ajánlatot, de ha nem lenne megadva az életkor, akkor elutasítaná. Illetve senki nem adja meg az életkorát, és az utas ekkor elfogadja az összes sofört.

\section{Következtetések}

Az előzőekben leírtakból akár arra is következtethetnénk, hogy nem kell mást tenni, csak az idősebb munkavállalók, példánkban az idősebb sofőrök véleményét megváltoztatni. Ha az $\mathrm{M}$ típusból sikerülne $\mathrm{R}$ típust faragni, akkor az egyensúlyban a sofórnek meg kell adnia életkorát. Mivel pedig így az utas sose kerül a „Nem ad meg" információs halmazba, ezért minden valós esetben elfogadja a sofórt. Illetve a másik egyensúlyban, ha a társadalom elfogadja az idősebb sofórt, ha nincs megadva az életkoruk, akkor egyik típusnak se kell megjelölnie életkorát. 
A kérdés azonban korántsem ilyen egyszerü. Az idősebb sofőrök vélekedése ugyanis nem független az általános társadalmi normáktól, elképzelésektől. Saját típusukat egyéni adottságaik mellett ezek a társadalmi kötöttségek is alakítják. A tanulmányunkban bemutatott játék a jelenlegi társadalmi elképzelések - lásd a kérdőívezés eredményét - által meghatározott szituációt adja vissza. Ahhoz, hogy „áttranszformáljuk” az M típusú sofơrt R típusúvá, ezeket az elképzeléseket, és nem a sofőrök vélekedését kell megváltoztatnunk. A vélekedések ugyanis nem függetleníthetők az általános társadalmi elfogadottságtól. Ugyancsak a társadalmi meghatározottság következménye, ha egy adott munkavégzésre elfogadnak bárkit, életkortól függetlenül. Ekkor viszont egyáltalán nem feltételezhető, hogy két típus, $\mathrm{R}$ és $\mathrm{M}$ alakuljon ki a soförök közt.

Végül arról sem szabad megfeledkeznünk, hogy az R típusúak arányának a kérdéses korosztályon belüli ceteris paribus megváltoztatása nem biztos, hogy a valóságban is minden más változatlansága mellett realizálódhat. Azaz az arányok megváltozása esetleg együtt járhat az utasok véleményének módosulásával, ami ezek után már csak másfajta modellkörnyezettel írható le.

\section{A. Függelék}

Az online-kérdőívünk kérdései:

1. Az Ön neme?

- Nő

- Férfi

2. Az Ön születési éve?

3. Képzelje el, hogy valamilyen szolgáltatói feladatot vállal internetes hirdetés segítségével (pl. korrepetálás, sofőrködés, takarítás stb.). Jelentkezéskor beírhatja életkorát, de azt senki nem ellenőrzi. Véleménye szerint életkorának van jelentősége abban, hogy mennyi ügyfele (fogyasztója) lesz?

- Igen, van jelentösége

- Nem, nincs jelentősége

4. Ön megadna valamilyen életkort? Ne felejtse, nem szükséges megadnia a tényleges életkorát!

- Igen

- Nem

5. (Csak abban az esetben, ha az előbbi kérdésre igennel válaszolt.) Milyen életkort adna meg? 


\section{Hivatkozások}

[1] Arrow, K. J.: Higher Education as a Filter, Journal of Public Economics, Vol. 2 No. 3, pp. 193-216 (1973). DOI: 10.1016/0047-2727(73)90013-3

[2] Berde, É.: Older People in the Platform Economy, Frontiers in Sociology, Vol. 4 No. 8 (2019). DOI: $10.3389 /$ fsoc.2019.00008

[3] Berde, É. ÉS TőKÉs, L.: Platformokon keresztül dolgozó idősebb munkavállalók. Az idősebb soförök példája az Oszkárnál, Köz-Gazdaság, online first 2020/1 (2020).

URL: http://unipub.lib.uni-corvinus.hu/4713/

[4] Binmore, K. G.: Fun and Games: A Text on Game Theory. D.C. Heath, Lexington, p. $602(1992)$.

[5] Button, P.: Population Aging, Age Discrimination, and Age Discrimination Protections at the 50th Anniversary of the Age Discrimination in Employment Act, National Bureau of Economic Research, (2020). DOI: 10.3386/w25850

[6] Cho, I. K. And Kreps, D. M.: Signaling Games and Stable Equilibria. The Quarterly Journal of Economics, Vol. 102 No. 2, pp. 179-221 (1987). DOI: 10.2307/1885060

[7] HanusheK, E. A.: The Economics of Schooling: Production and Efficiency in Public Schools, Journal of Economic Literature, Vol. 24 No. 3, pp. 1141-1177, (1986).

[8] Harsányi, J. C.: Games with Incomplete Information Played by "Bayesian" Players, Part I. The Basic Model, Management Science, Vol. 14 No. 3, pp. 159-182 (1967). DOI: $10.1287 /$ mnsc.14.3.159

[9] Harsányi, J. C.: Games with Incomplete Information Played by "Bayesian" Players, Part II. Bayesian Equilibrium Points. Management Science, Vol. 14 No. 5, pp. 320-334 (1968a). DOI: $10.1287 /$ mnsc.14.5.320

[10] Harsányi, J. C.: Games with Incomplete Information Played by "Bayesian" Players, Part III. The Basic Probability Distribution of the Game. Management Science, Vol. 14 No. 7, pp. 486-502 (1968b). DOI: 10.1287/mnsc.14.7.486

[11] Heckman, J. J., Stixrud, J., And Urzua, S.: The Effects of Cognitive and Noncognitive Abilities on Labor Market Outcomes and Social Behavior, Journal of Labor Economics, Vol. 24 No.3, pp. 411-482 (2006). DOI: 10.3386/w12006

[12] Huws, U., Spencer, N., Syrdal, D. S., and Holts, K.: Work in the European Gig Economy: Research Results from the UK, Sweden, Germany, Austria, the Netherlands, Switzerland and Italy, Foundation for European Progressive Studies, Brussels, (2017).

[13] Ilmakunnas, P. and Maliranta, M.: Aging, Labor Turnover and Firm Performance, ETLA Discussion Papers 1092, The Research Institute of the Finnish Economy, Helsinki, (2007). DOI: $10.2139 /$ ssrn.984683

[14] Kreps, D.: A Course in Microeconomic Theory. Princeton University Press, Princeton, (1990).

[15] Lazear, E. P. and Rosen, S.: Rank-order Tournaments as Optimum Labor Contracts. Journal of Political Economy, Vol. 89 No. 5, pp. 841-864 (1981). DOI: 10.1086/261010 
[16] Mincer, J.: Schooling, Experience, and Earnings, Human Behavior \& Social Institutions, No. 2 (1974).

[17] Osborne, M. J. And Rubinstein, A.: A Course in Game Theory, MiT press, Cambridge, Massachusetts London (1994).

[18] PwC, Pwc Golden Age Index. Unlocking a Potential \$3,5 Trillion Prize from Longer Working Lives, PricewaterhouseCoopers (2018).

https://www.pwc.co.uk/economic-services/golden-age/golden-age-index-2018-final-sanitised. pdf

[19] Roth, A. E. And Sotomayor, M.: Two-sided Matching, Handbook of Game Theory with Economic Applications, Vol. 1, pp. 485-541 (1992). DOI: 10.1016/S1574-0005(05)80019-0

[20] SleE, T.: What's Yours is Mine: Against the Sharing Economy, Or Books, New York, London (2017). DOI: $10.2307 /$ j.ctv62hf03

[21] Spence, M.: Job Market Signaling, The Quarterly Journal of Economics, Vol. 87 No. 3, pp. 355-374 (1973). DOI: 10.2307/1882010

[22] Stiglitz, J. E.: The Theory of "Screening", Education, and the Distribution of Income, The American Economic Review, Vol. 65 No. 3, pp. 283-300 (1975).

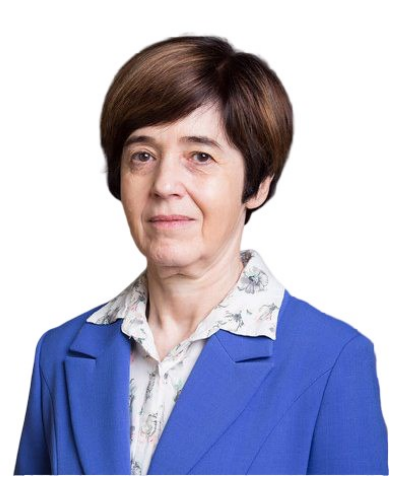

Berde Éva 1988 óta dolgozik a Budapesti Corvinus Egyetemen, illetve jogelődjeinél. Végzettsége szerint közgazdász és matematikus. Mikroökonómiai jellegü tárgyakat tanít. Kutatási témái: a demográfia kihatásai a gazdasági életre, valamint a hakni gazdaság. 2012-ben szerezte meg habilitációját. 2015-ben egyetemi tanárnak nevezték ki. Szintén 2015-ben alapította a Közgazdasági Karon a Demográfia és Gazdaság Kutatóközpontot, mellyel azóta több pályázatot is nyertek. Az MTMT-ben több mint 120 jegyzett publikációja szerepel. Jó néhány végzett $\mathrm{PhD}$ hallgatója van, és jelenleg is több $\mathrm{PhD}$ hallgató konzulense.

BERDE ÉVA

Budapesti Corvinus Egyetem

Mikroökonómiai Tanszék

Egyetemi tanár

1093 Budapest, Fővám tér 8. - E. 223.

eva.berde@uni-corvinus.hu 


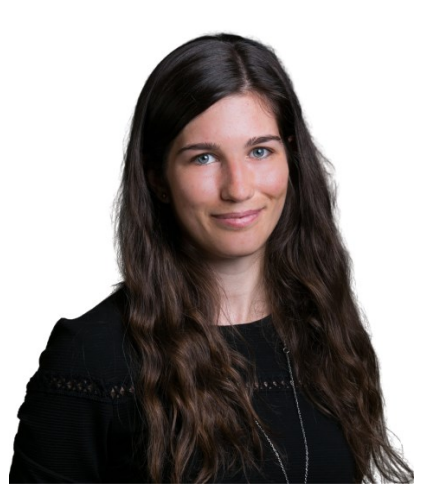

Kuncz Izabella 1988-ban született Budapesten. Alapszakos diplomáját Alkalmazott közgazdaságtan szakon szerezte meg 2009-ben, 2011-ben pedig Közgazdasági elemző szakon kapott mesterszakos diplomát a Budapesti Corvinus Egyetemen. Ezt követően kezdte meg doktori tanulmányait az Általános és Kvantitatív Közgazdaságtan Doktori Iskola jogelődjében. Kutatási témája a demográfiai változások makrogazdasági hatásai. 2015-ben csatlakozott a Demográfia és Gazdaság Kutatóközponthoz. Makroökonómia és Makroökonómiai modellépítés kurzusokat tart alapszakos hallgatóknak, Haladó makroökonómiát pedig mesterszakosoknak. Oktatói munkáját 2016-ban Az Év Oktatója kitüntetéssel, illetve a 2016/2017. akadémiai évben a Budapesti Corvinus Egyetem Kenneth Rice Díjával jutalmazták, 2019-ben pedig elnyerte a Hallgatói Önkormányzattól „A félév előadója címet”, illetve Rektori Kitüntető Oklevélben részesült.

\section{KUNCZ IZABELLA}

Budapesti Corvinus Egyetem

Makroökonómiai Tanszék

egyetemi tanársegéd

1093 Budapest, Fővám tér 8. - E. 225.

izabella.kuncz@gmail.com

\section{WHO ARE INTERESTED IN REVEALING THEIR AGE?}

\section{Éva Berde, Izabella Kuncz}

Newly emerged platforms offer lots of working opportunities for everyone, including older people. Oszkar, the Hungarian On-line Passenger Intermediary System is one of the examples where many older people joined the platform as workers (drivers). Since the establishment of Oszkar the number of drivers has been increased continuously, and the share of older drivers has grown even more. However a significant fraction of older drivers have not revealed their age when they filled in their own form on the webpage. An online survey was used to find what older people think about their social acceptance when their age is revealed, and additionally a game theoretic model was built to describe the behavior of older drivers. Both approaches showed that there exists only a mixed equilibrium where a certain portion of older workers prefer to hide their age.

Keywords: Platform economics, older drivers, on-line survey, game-theoretic model 